\title{
Problems of Institutional Structures Formation to Support Talented Youth at the Regional Level
}

\author{
Asya Arutyunova \\ Department of State and Municipal Management \\ FSBI of HE Kuban State Technological University \\ Krasnodar, Russia \\ aru-asya@yandex.ru
}

\begin{abstract}
The article attempts to justify the need to create institutional systems to identify and support creatively gifted children. The paper analyzes the institutional problems of the modern system of support for talented youth, both at the Federal and regional levels in the Russian Federation. An analysis of the main activities to support talented and active young people at all levels of government was carried out. Based on the analysis, it can be concluded that, on the one hand, in our country there are prerequisites for the creation of an effective mechanism to identify and support young people with creative potential"Federal level - regional level - municipal level", on the other hand, for a number of reasons, these prerequisites remain largely unfulfilled. As a result of the conducted research, a number of problems that constrain the state policy on support of talented youth and interfere with its effective implementation was revealed. The key problems are: low level of attention to the need to form a mechanism for the development of talented youth; focus on increasing the number of institutions working with youth, and their low degree of interaction and interconnection; low level of funding for programs to identify and support young people with creative potential; lack of effective mechanisms for monitoring the dynamics of creativity among children in the regions of the country; insufficient regulatory framework. A mechanism was proposed to identify and support talented youth through the formation of a network infrastructure.
\end{abstract}

Keywords: talented youth, management system, grant support, potential disclosure, talent identification

\section{INTRODUCTION}

In the modern world the relevance of the task of selecting and supporting talented youth in Russia is beyond doubt. The rapidly developing information society creates a demand for a mobile, innovative thinking person who is able to work effectively both in a team and independently. Therefore, modern society requires a person with extraordinary, creative thinking, a broad outlook, able to set and solve non-standard tasks. In this regard, the state and society have a global strategic task to form such a person, and at the same time, the conditions that help the fullest disclosure of the professional and creative potential of the individual for the benefit of himself, his family and his country [1]

Currently the system of identification and support of talented youth in Russia is in the process of formation [2]. Legislation to work with talented youth is still controversial. In some regulations there are no mechanisms of implementation.

\section{MethodS AND RESUltS}

The categorical apparatus of the creative potential of the human factor and the capitalization of this potential are disclosed in the writings of L. Abalkin, G. Becker, M. Castels, G. Kleiner, K. Marx, E. Madison, J. Psacharopoulos, John Stiglitz, J. Schultz, L. Edvinsson. Institutional aspects of the participation of the education subsystem in the formation of the creative potential of the individual are studied in the works of O. Belokrylova, V. Volchik, B. Ernzkyan, O. Inshakov, S. Kirdina, Yu. Latov.

The article uses the methods of systematic, monographic, statistical, structural and logical research. Each of the methods is used based on the functional capability.

\section{Discussion}

Today in Russia, the main attention is paid to programs and projects aimed at finding and one-time support for talented youth [3]. It is youth that act as a resource for generating sustained competitive advantages: they make most of scientific discoveries, take many social and economic initiatives, develop a significant number of technical improvements, and offer a maximum of "fresh" ideas.

Currently, various activities are carried out to support talented and active young people, which are implemented at the Federal and regional levels [4].

Every year, 500 grants from the President of the Russian Federation to young Candidates of Sciences and their supervisors are awarded on a competitive basis, as well as 100 
grants from the President of the Russian Federation to young Doctors of Sciences [5].

Events are held to support and identify talented youth with the participation of the Ministry of Education and Science of Russia (annual interdepartmental open competition for the best scientific work of students in Natural, Technical and Humanitarian Sciences in higher educational institutions of the Russian Federation; international youth scientific Olympiad "Lomonosov"; the program "Step into the future", "Start in science", "Junior", "Youth, Science, Culture", the competition "Students, post-graduates and young scientists for small science-intensive business - Polzunov's grants", the annual all-Russian Youth Delphic Games, etc.) [6]. The Ministry of Culture of Russia has its own system of support for talented youth [7].

It should also be noted that currently the country does not have a comprehensive system of development and use of the potential of creative youth in the interests of socio-economic development of Russia [8].

Unfortunately, today there is still no system of support for talented young people and providing conditions for their future professional activities and the realization of their creative potential in Russia. Often, the search for and support of talented youth is limited only to competitive procedures and their advertising campaigns.

The list of well-known projects and programs in most cases is dominated by events in the field of show business and professional sports, and creative gifted youth (especially in the field of science, innovative entrepreneurship, art) does not find proper state support, recognition and implementation in Russia [9]. In particular, there are no clearly defined priorities in the national project "Education" from the point of view of the state support of creatively gifted youth (Federal Agency for Youth Affairs "Rosmolodezh"). Among the five categories of awards aimed at supporting talented youth, the priority direction - "Scientific and technical creativity and educational and research activities" - is slightly ahead of amateur sports and artistic creativity. They account for $39 \%, 21 \%$ and $24.5 \%$, respectively, of those awarded within the framework of state support for talented youth [10].

At the same time, strategically important issues remain unnoticed: the selection and support of projects that have proven their effectiveness in working with young talents, the promotion of the image of young talents, drawing public attention to the need to work with children and adolescents, the creation of tools for talents, interaction with each other, the implementation of activities, the survey of their worldview, the development of vectors of personal development [11].

Thus, the key task is, first, the creation of appropriate conditions for the formation and disclosure of young talentsthe creation of conditions that help to develop the human resources potential of the innovative economy of Russia, ensuring, among other things, recruitment mechanisms and renewal of the national elite, educated in the spirit of patriotism respect for their country and future generations, conscientious and responsible attitude to their work aimed at sustainable development of society [12]. At the same time, such an environment should take into account the positive experience of working with a talented person accumulated in the country in previous years, including in the Soviet period, as well as rely on the best foreign practices.

In the Russian Federation, the state encourages educational centers to work with talented children, providing them with substantial financial support [13]. The forecasts made in 2011 were not justified (Fig. 1).

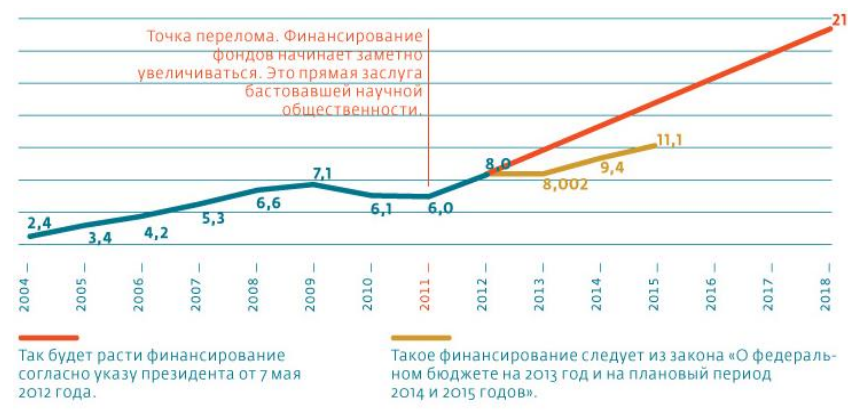

Fig. 1. Financing of the Russian Foundation for basic research (RFBR) in 2004-2018 (billion rubles) (Source: "Science and innovation" data)

The second strategic objective is to develop and implement a well-functioning system of interrelated mechanisms and measures to identify and support talent.

The successful functioning of this system is possible only if there are clear goals, consistent executive discipline and personal responsibility for the rational use of existing organizational, human, financial and other resources. However, in practice, the largest and most titled Fund of the Russian Federation for work with talents uses only $5 \%$ of the provided cash subsidies, while the fate of gifted children after they graduate from educational institutions is not monitored by the state in any way [14].

Federal budget allocations for science and its development are declining (Fig. 2), at the same time, in comparison with the leading countries, the level of GDP for basic research is much lower.

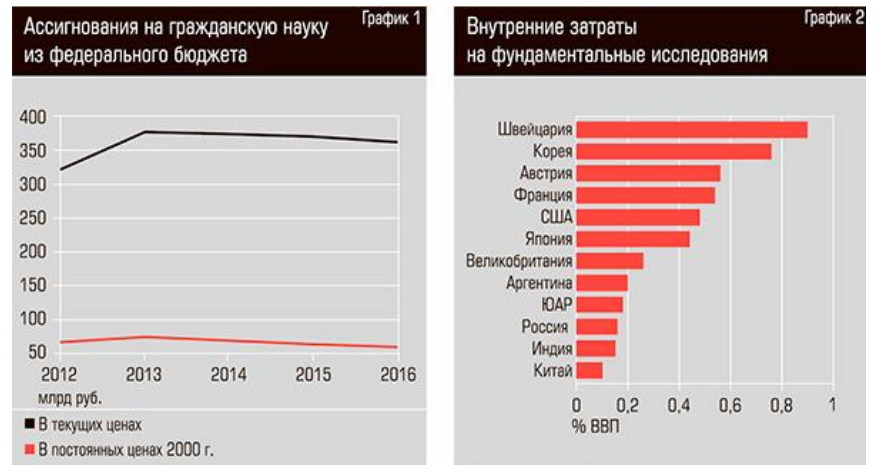

Fig. 2. Appropriations for civil science from the Federal budget. Volume of internal expenditures for basic research (Source: Institute of science development problems RAS data)

State support may consist in stimulating the attraction to science-intensive, advanced, promising areas of production of that part of the talented youth, which during the entire period 
ensure the development and implementation of abilities of all

of study in state educational institutions has been provided with significant state support. Today, when the Federal register of gifted children is approved and maintained in the Russian Federation, the implementation of such a project is not difficult technically.

Thus, there is a pessimistic picture: our state trains, conducts large-scale work to identify and support the talented potential of the country, and then many of these talents leave Russia forever.

The experience of developed foreign countries testifies to the expediency of creating a search system for potential talented young people from an early age [15]. Methods of early testing, scientific and educational programs are aimed at the youngest, and allow you to get acquainted with the simplest mechanisms, and scientific experiments have become widespread abroad. In Russia, this direction is almost not developed. Methods of early diagnosis of gifted children for a number of years have only experimental value and extremely limited distribution. The practical stage of search and identification of talented children begins not earlier than in primary school age. With rare exceptions, before entering an educational institution, the question of a child's greater ability to Sciences or Humanities is not considered in principle [16].

This leads to the following problem: the complexity of the implementation of early development programs of the identified potential due to the lack of practice of identifying gifted children at an early stage. Currently, such programs outside the framework of the experiment are not common in the territory of the Russian Federation. It should also be noted that early testing systems are not widely used in principle. In fact, the identification of gifted children occurs only as a result of their academic progress in the educational process.

Therefore, it is necessary to create a holistic system of identification, support and development of talented youth in the Russian Federation, aimed at identifying and developing the creative potential of young citizens to ensure their selfrealization and participation in the development of a strong and prosperous Russia [17].

Also important is the active work on the creation of specialized centers that coordinate the work of educational institutions for gifted children in the regions of the Russian Federation.

Thus, in our opinion, it is advisable to establish a system of personal grants allocated to support this process and held by special funds financed from various sources and accredited territorial authorities.

The first step is to create a network of funds in the context of the regions of the Federation. The Fund for assistance and support of talented youth will be non-commercial in nature and will implement the procedure for granting grants financed from various sources (Federal and regional budget funds, as well as funds provided by commercial organizations on a charitable basis).

Based on the proposed Fund should be established nationwide system of identifying and developing young talents, formed as a complex of programs and activities that children and young people to achieve outstanding results in their chosen sphere of professional activity.

The main objectives of this system for identifying and developing young talents will be:

a) creating conditions for the development of the abilities of all children and young people regardless of their place of residence, social status and financial capabilities of the family;

b) support of educational institutions of the highest category for children, adolescents and young people who have shown outstanding abilities, dissemination of the best practices of institutions and best teaching methods.

The Foundation's work should be based on the following main principles:

a) the priority of the interests of a child or young person, his right to freedom of choice of profession, care for his health;

b) accessibility and openness;

c) reliance on highly qualified personnel, the best educational institutions, advanced teaching methods;

d) individual approach to learning and continuity at all levels of education;

e) interagency and network communication;

f) public and professional control; [18].

g) combination of state and public initiatives and resources

The algorithm of the accreditation procedure of the Fund is seen as follows (Fig. 3).

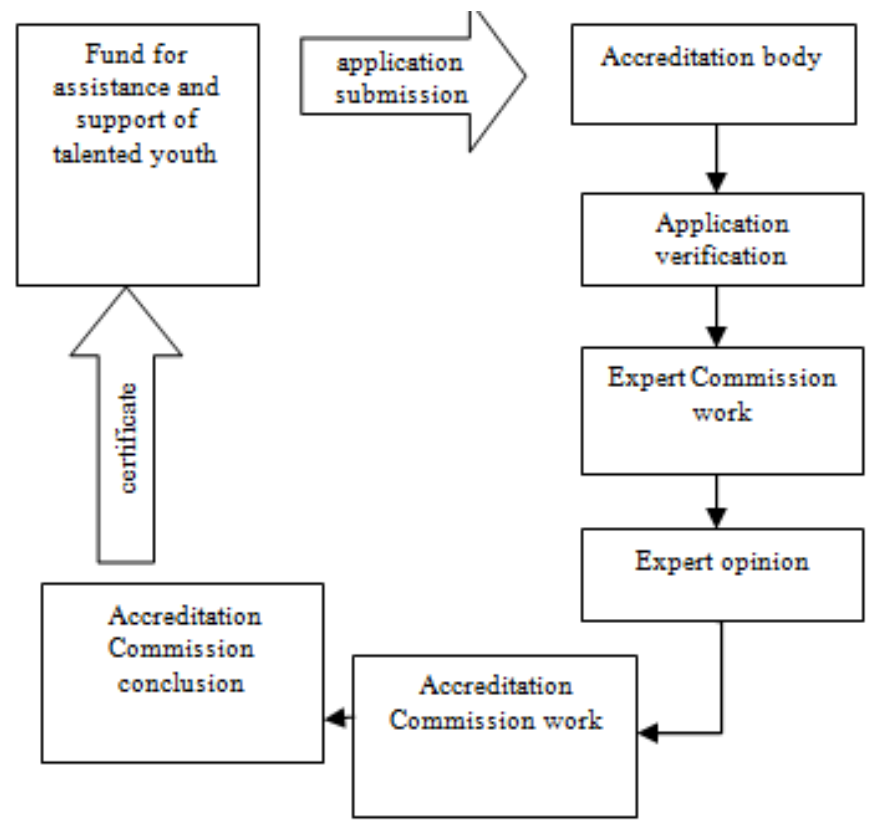

Fig. 3. Step-by-step algorithm of the Fund for assistance and support of talented youth accreditation (Source: author's materials) 


\section{REFERENCES}

order to monitor the activities of the Funds and the targeted expenditure of funds, we propose a system of mandatory accreditation by regional authorities [19].

Accreditation should be conducted in order to recognize the state status of the Fund. From the moment of state accreditation the Fund also acquires the right to be included in the scheme of centralized state financing in accordance with the established procedure.

State accreditation of the Fund to be the accreditation body of the Federal body of Executive power exercising functions on control and supervision in the sphere of education, or Executive authority of the subject of the Russian Federation, carrying out powers of the Russian Federation in the field of education.

We will define a mechanism for providing support to talented youth in the form of grants from the Fund. Support will be provided free of charge and irrevocable.

\section{CONCLUSIONS}

It is necessary to emphasize the importance of further systematic work with talented students in the Russian Federation at the state level, including the modernization of educational institutions, training and professional development of teaching staff as the main link in the development of talented children [20].

The main directions in development of the system of state support for talented and initiative youth should be:

- development of a network of educational institutions working with talented children and young people;

- scientific, methodological and personnel support of work with talented children and youth;

- creating conditions for the inclusion of talented children and young people in intellectual and creative activities;

- creation of a single information space to ensure the system of work with talented youth;

- implementation of a set of measures for more effective inclusion of talented youth in intellectual and creative activities, as well as graduates of educational institutions - in scientific, administrative and other professional activities;

- development of international cooperation in the sphere of work with talented children and youth.

The implementation of these tasks will contribute to the socio-economic and cultural development of the Russian Federation [21].

Great hopes are pinned on young people as one of the main driving forces in dealing with negative impacts of the global financial and economic crisis. That is why in the Russian Federation care for the young generation is considered as a long-term investment in a future stable and prosperous society.
[1] Concept of long-term socio-economic development of the Russian Federation for the period up to 2020, approved by the order of the Russian Federation Government of November 17, 2008, no. 1662-p [Electronic resource]. Available at http://www.consultant.ru/document/cons doc LAW 82134/28c7f9e359 e8af09d7244d8033c66928fa27e527/ (Accessed: 30 June 2019).

[2] Decree of the President of the Russian Federation of April 6, 2006, no. 325 (ed. of November 9, 2010) "On measures of state support for talented youth" [Electronic resource]. Available at: https://base.garant.ru/6198652/ (Accessed: 30 June 2019).

[3] Concept of the Federal target program "Youth of Russia for 2016-2020", Ministry of Education and Science of the Russian Federation, 2015 [Electronic resource]. Available at: https://minobrnauki.gov.ru/ (Accessed: 30 June 2019).

[4] Federal law of 24 July 1998 "On basic guarantees of the child's rights in the Russian Federation", no. 124-FZ, 1998 [Electronic resource]. Available http://www.consultant.ru/document/cons_doc_LAW_19558/ (Accessed: 30 June 2019).

[5] On measures of the state support of talented youth: Decree of the President of April 6, 2006, no. 325 (in the edition of Decrees of the President of the Russian Federation of 09 Novemeber 2010 no. 1413) [Electronic resource] Available at: http://www.consultant.ru/document/cons_doc_LAW_59463/ (Accessed: 30 June 2019).

[6] Resolution of the Government of the Russian Federation of May 27, "On awards to support talented youth", 2006, no. 311 [Electronic resource]. Available at: http://www.consultant.ru/document /cons_doc_LAW_60517/(Accessed: 30 June 2019).

[7] S. V. Doroshenko and E. P. Eroshenko, "University partnership system as a factor in the development of youth entrepreneurship", Economic and Social Changes: Facts, Trends, Forecast, 2018, V. 11, no. 6, pp. 244-258.

[8] F. Dudyrev, I. Froumin, V. Maltseva, E. Loshkareva, and E. Tatarenko, "Worldskills approaches to comparable skills assessment in vocational education", Modern education analytics, 2019, no. S8 (30), pp. 5-44.

[9] S. K. Amandykova, M. K. Syrlybayev, S. A. Saimova, B. O. Altynbassov, Z. S. Berdiyarova, A. M. Tassova, S. Z. Suleimenova and A. O. Askarova, "The role of science and education in the formation of national human capital: kazakhstan experience", Indian Journal of Science and Technology, 2016, T. 9, no. $27,97657 \mathrm{p}$.

[10] I. G. Kuznetsova, Yu. N. Surikov, L. M. Votchel, M. Yu. Aleinikova, O. Yu.Voronkova, and R. A. Shichiyakh,"The methodological aspect of human capital formation in the digital economy", International Journal of Mechanical Engineering and Technology, 2019, T. 10, no. 2, ppP. 1020-1030.

[11] L. I. Vanchukhina, T. B. Leybert, E. A. Khalikova, and A. R Khalmetov, "New approaches to formation of innovational human capital as an element of institutional environment", Espacios, 2018, T. 39, no. $1,22 \mathrm{p}$

[12] A. Aletdinova and A. Koritsky, "The relationship of ict with human capital formation in rural and urban areas of Russia" Communications in Computer and Information Science, 2018, T. 859, pp. 19-27.

[13] S. V. Titova, Yu. N. Surikov, O. Yu. Voronkova, T. V. Skoblikova, I. V. Safonova, and R. A. Shichiyakh, "Formation, accumulation and development of human capital in the modern conditions", International Journal of Economics and Business Administration, 2019, T. 7, no. 2, pp. 223-230.

[14] "Draft concept and program for the development of state support system for talented and gifted youth for the period 2020", All-Russian youth magazine "Our Youth" [Electronic resource]. Available at: http://nashamolodezh.ru/go/projects/proekt_koncepcii_i_programmy _razvitija_sistemy_gosudarstvennoj_podderzhki_talantlivoj_i_iniciativn oj_molodezhi_na_period_2020_god.html (Accessed: 18 July 2019).

[15] T. V. Kuprina, Ja. Kultan, T. Kozik, and S. M. Minasyan, "Meaningfulness of academic migrants' education, its assessment and 
and Social Changes: Facts, Trends, Forecast, 2018, T. 11, no. 6, pp. 244-258.

modeling on it-based technologies", The economy of the region, 2016, T. 12, no. 2, pp. 485-498.

[16] A. V. Merenkov, N. L. Antonova, and N. G. Popova, "Leadership potential of professional teacher associations in Russia: formation of middle leaders", Journal of Language and Education, 2019, T. 5, no. 3 (19), pp. 70-82.

[17] I. N. Karelin, "Dependence of wages on the duration of training and length of service in the russian economy sectors", In the collection: Actual problems of electronic instrument engineering (apeie), proceedings apeie, 2018 14th international scientific-technical conference, vol. 8, pp. 379-383.

[18] S. V. Doroshenko and E. P. Eroshenko, "University partnership system as a factor in the development of youth entrepreneurship", Economic
[19] T. Ya. S. Solov'eva, A. V. Popov, A. Caro-Gonzalez, and Li Hua, "Social innovation in Spain, China and Russia: key aspects of development", Economic and Social Changes: Facts, Trends, Forecast, 2018, T. 11 , no. 2, pp. 52-68.

[20] A. M. Rudenko, V. I. Rodionova, and V. N. Stepanova, "Social fears in the context of security concern: social and philosophical analysis", Advances in Intelligent Systems and Computing, 2019, T. 726, pp. 1144-1155.

[21] E. V. Romanov, "What capitalism does Russia need?: methodological guidelines of the "new industrialization"", Economic and Social Changes: Facts, Trends, Forecast, 2017, T. 10, no. 2, pp. 90-108. 